\title{
大気中のカルタップ及びチオファネート メチルの分析について
}

\author{
神浦 俊一, 中土井 隆 \\ 大阪市立環境科学研究所 \\ （宁543 大阪市天王寺区東上町 $8-34$ )
}

[平成 4 年 9 月 16 日受理］

\section{Analysis of Cartap and Thiophanate-methyl in Air}

\author{
Toshikazu KAMIURA and Takashi NAKADOI \\ Osaka City Institute of Public Health \\ and Environmental Sciences \\ (8-34, Tojo-cho, Tennoji-ku, Osaka 543)
}

[Received September, 16, 1992]

\begin{abstract}
Summary
Cartap in air, which was collected on the Carbotrap ${ }^{\mathrm{TM}}$ sorbent and introduced into GC / MS by using the TCT instrument, was determined as nereistoxin. The analytical method for thiophanate-methyl in air was composed of sampling with the ascorbic acid-impregnated paper and high-performance liquid chromatography with UV detection. The detection limit of nereistoxin was $0.3 \mathrm{ng} / \mathrm{m}^{3}$ for $30 \mathrm{~L}$ of air sampled, and that of thiophanate-methyl was $22 \mathrm{ng} / \mathrm{m}^{3}$ for sum of 5 samples, where $200 \mathrm{~L}$ of air was collected in each. Both compounds were not detected in any samples.
\end{abstract}

Key Word: カルタップ, ネライストキシン, チオファネートメチル, GC/MS, HPLC/UV

\section{1.はじめに}

今日, 我々の生活のまわりで農薬を含めて非常に多く の化学物質が使用され，その結果として水や大気などの 環境中から種々の化合物が検出されている1”。

現在，検索可能な物質の数は，使用されているものの ほんの一部であり，技術的解決は困難だとしてもこの ギャップをできるだけ埋めることは重要なことである。 そのための一つの基本的な対応として GC / MS による一 斉分析法の開発が行われている ${ }^{2.3)}$ 。

しかしながら物質によつては熱的安定性が良くないも のや酸化を受けやすいもの，あるいは非常に極性の強い ものなど GC/MSによる一斉分析を行えないものもあ り,これらは個別の対応をせざるを得ない。たとえば今
回検討したカルタップは空気酸化を受けて18時間後には ネライストキシンに変化してしまい"， チオファネート メチルは熱的に不安定であるため GCによる分析ができ ないので, 高速液体クロマトグラフィーによる分析が行 われている5!。しかしチオファネートメチルは幅広い紫 外吸収を持つため, 共存物質の影響を受けやすいので, 大気中のチオファネートメチルの分析にそのまま適用で きない。また後述するように試料捕集の際, 空気酸化を 受けるためそれを防ぐ工夫も必要である。

本報では，大気中のカルタップの分析法として，大気

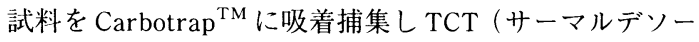
プションコールドトラップ)法により GC / MS に導入し, ネライストキシンとして測定する方法を，またチオファ ネートメチルの分析法としてアスコルビン酸含浸石英㵶 
維ろ紙による捕集と HPLC-UV 法による測定法を検討し たので報告する。

\section{2. 実験方法}

\section{1 装置と試薬}

ネライストキシン (Ner と略す) の測定に用いたGC/ MS システムは, HP5890ガスクロマトグラフ(ヒューレッ トパッカード社製)，DX303マススペクトロメーター(日 本電子社製）及びTCT 導入装置（クラムパック社製） からなる。分析カラムは化学結合型 DB-5 (30m X $0.25 \mathrm{~mm}$ i.d. 膜厚 $0.25 \mu \mathrm{m})$ を用いた。その昇温プログ ラムは次の通りである。 $80^{\circ} \mathrm{C}$ から $5{ }^{\circ} \mathrm{C} / \mathrm{min} て ゙ 165^{\circ} \mathrm{C}$ まで, 更に $10^{\circ} \mathrm{C} / \mathrm{min}$ で $250^{\circ} \mathrm{C}$ まで昇温し，4.5分間保持した。

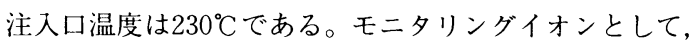
定量用に $\mathrm{m} / \mathrm{z} 149$ を, 確認用に $\mathrm{m} / \mathrm{z} 70,103$ 用いた。イ

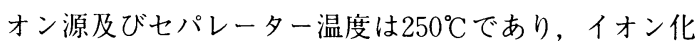
電压は70eVである。ヘリウムは定圧 $0.76 \mathrm{kgf} / \mathrm{cm}^{2}$ である。

チオファネートメチル（TMと略す）の分析には, 島 津液体クロマトグラフ LC-3A 及び島津分光光度計 SPD-1を用いた。使用したカラムはSupelcosil ${ }^{\mathrm{TM}}$ LC-18-DB $(25 \mathrm{~cm} \times 4.6 \mathrm{~mm}, 5 \mu \mathrm{m})$ であり，50\%メタノー ル水溶液を移動相として $1.0 \mathrm{ml} / \mathrm{min}$ の流速で用いた。恒

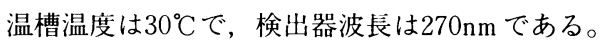

ネライストキシンシュウ酸塩（和光純薬工業社製，含 量 $98.4 \%$ ) の標準溶液はメ夕ノールで調製した。TM（和 光純薬工業社製, 含量 $99.2 \%)$ はその $100 \mathrm{mg}$ を $100 \mathrm{ml}$ の メタノール/アセトン $(90 / 10)$ に溶解し標準原液とした。 $100 \mathrm{ppm}$ 前後までメタノールで溶解し, その後ジクロロ メタンで希釈し HPLC 用標準溶液とした。この標準溶液 は用時調製する。

使用した溶媒はすべて残留農薬試験用である。

\section{2 方 法}

Nerの分析はピリジン, 2-ビニルピリジンの測定 ${ }^{6)}$ と 同梯にCarbotrap ${ }^{\mathrm{TM}} 0.1 \mathrm{~g}$ を充填した捕集管に $0.5 \mathrm{~L} / \mathrm{min}$ の流量で大気を $30 \mathrm{~L}$ 吸引し, 吸着されたサンプルを $230^{\circ} \mathrm{C}$ で 5 分間加熱脱着し, TCT 装置により GC/MSに導入 した。検量線は各濃度の標準溶液 $1 \mu 1$ をマイクロシリ ンジにとり捕集管に注入し, 純化した窒素ガスで 2,3 分展開後，同様の方法により GC/MSに導入して得られ たピーク面積と注入量とから作成した。

大気中の TMの捕集はアスコルビン酸含浸ろ紙により $5 \mathrm{~L} / \mathrm{min}$ で $200 \mathrm{~L}$ 吸引した。このろ紙は直径 $47 \mathrm{~mm}$ の石 英䋐維乃紙 (東洋ろ紙社製) に塩酸酸性アスコルビン酸 $(10 \mathrm{~g} / \mathrm{L}, \mathrm{pH}=2)$ をピペットで均一に含浸させ,一晚 風乾した後, 使用した。捕集した試料 $3 \sim 5$ 個を, $50 \mathrm{ml}$ の比色管に切取り, 水水中で $50 \mathrm{ml}$ の $10 \%$ アトン 水溶液で 2 回超音波抽出し, メンブランフィルターでろ
過後（東洋万紙社製， $0.45 \mu \mathrm{m}$ ），約 $100 \mathrm{ml}$ のろ液を 10 $15 \mathrm{ml} / \mathrm{min}$ の速度でCarbopack B (120-400メッシュ, $250 \mathrm{mg}$ ，内径 $12 \mathrm{~mm}$ ，スペルコ社製）上に流下させる。 $2 \mathrm{ml}$ のメタノールで洗浄後, アンモニアを含むジクロ ロメタンノメタノール (70/30, 10ml 当り $100 \mu 1$ の $28 \%$ アンモニア水を添加）溶液 $5 \mathrm{ml}$ で溶出させ, 分解を防 ぐためすぐに $10 \% \mathrm{HCl}$ 水溶液 $2 \mathrm{ml}$ を添加する。手で激 しく振とうし，2 層分離したジクロロメタン層（下層） を分離し, さらに上層のメタノールに等量のジクロロメ タンを加えて再度抽出後, ジクロロメタン層を分離する。 ジクロロメタン層をあわせ, $\mathrm{N}_{2}$ 気流下で $0.2 \mathrm{ml}$ まで濃縮 する。このうちの $50 \mu 1$ あるいは $100 \mu 1$ をHPLCに注入 する。各濃度の TM 標準液50 $\mu \mathrm{l}$ を HPLCに注入して得 た検量線から濃度を算出する。

\section{3. 結果と考察}

\section{1 捕集法と脱離操作}

カルタップの分解物質であるネライストキシンは熱的 に安定であり7)，一般環境においては濃度が低いと予想 されるので, 全量分析の可能なCarbotrap ${ }^{\mathrm{TM}}$ による捕集 と TCT 法による GC/MS 導入による測定を行った。

$\mathrm{TM}$ は熱, 酸化物, 光, 金属などに対して敏感であり, 特に表 1 に示すように空気を吸引するのに伴って分解し その回収率が低下したので, 還元剤であるアスコルビン 酸含浸ろ紙による捕集を行った。UV 検出器を使用する ため共存物質による干涉を考慮して $10 \%$ アセトン水溶液 で抽出した後, Carbopack B による液固抽出処理 ${ }^{8)}$ を行っ た。当初, $10 \%$ メ夕ノール水溶液を使用したが, 低濃度 において回収率が低くなったので, TMはメ夕ノールよ りアセトンにより溶解しやすいことから10\%アセトン水 溶液に変更した。

Table 1 Effect of air volume on the recovery (\%)

\begin{tabular}{lrrrrr}
\hline \multicolumn{1}{c}{ Air volume } & 75 & 150 & 200 & 300 & 500 \\
\hline Qualtz filter $^{11}$ & 94 & 92 & - & 64 & 29 \\
Impregnated filter $^{11}$ & - & - & - & 94 & 60 \\
Impregrated filter $^{2)}$ & - & - & 86 & 85 & - \\
& & & & & \\
\hline
\end{tabular}

1) TM $(9.45 \mu \mathrm{g})$ was extracted with aqueous $10 \%$ methanol solution. Aqueous $10 \% \mathrm{HCl}$ solution $(1.25 \mathrm{ml})$ was added to the eluent immediately.

2) TM $(0.94 \mu \mathrm{g})$ was extracted with aqueous $10 \%$ acetone solution. Aqueous $10 \% \mathrm{HCl}$ solution $(2.0 \mathrm{ml})$ was added to the eluent immediately. 


\section{2 吸引空気量と回収率}

捕集管を 2 本直列につなぎ，最初の捕集管にNer 2 ng 添加し, 精製したボンベ空気 (Zero-U) を 30 L 通気後, 回収率を測定した。すべて最初の捕集管に保持されてい た。回収率は $97 \pm 6.1 \%(\mathrm{~N}=3)$ であった。

TM $9.45 \mu \mathrm{g}$ を石英乃紙上に担持させ, 室内空気で通 気すると表 1 に示すように, 吸引空気量の増加と共に回 収率は急激に減少する。これは TMの反応性が非常に高 く, 空気酸化を受けるものと思われる。アスコルビン酸 を含浸させたろ紙ではかなりの回復が見られるが，それ でも $500 \mathrm{~L}$ 吸引すると $60 \%$ 程度しか回収されない。(10\% メ夕ノール水溶液抽出, $1.25 \mathrm{ml}$ の $10 \% \mathrm{HCl}$ 水溶液で処 理）担持量 $0.94 \mu \mathrm{g}$ では回収率が更に悪くなったので, $10 \%$ アトン水溶液抽出, $2.0 \mathrm{ml}$ の $10 \% \mathrm{HCl}$ 水溶液処理 に変更した。200 L 及び300 L で85\%程度の回収率が得ら れた。よって約 $5 \mathrm{~L} / \mathrm{min} て ゙ 40$ 分間 $200 \mathrm{~L}$ 程度の空気を吸 引することとした。

\section{3 検量線と検出限界}

Ner $(m / z=149)$ の注入量とピーク面積は, 少なくと も0.1-0.8ngで良好な直線関係を示した。ただし0.1ng 以下では吸着に基づくと思われる不完全回収が生じ，検 量線は原点を通らない。

TM の検量線は少なくとも0-5.0ppm まで原点を通る 良好な直線関係を示した。

検出下限を $\mathrm{S} / \mathrm{N}=3$ とすると, Ner では試料採取量 30 $\mathrm{L}$ とした場合 $0.3 \mathrm{ng} / \mathrm{m}^{3}$ であり，TMでは $200 \mathrm{~L}$ 採取試料 を 5 個処理した場合で, $22 \mathrm{ng} / \mathrm{m}^{3}$ である。

\section{4 試料の保存性}

TM $0.94 \mu \mathrm{g}$, Ner $0.1 \mu \mathrm{g}$ をそれぞれの捕集装置に担 持させ,アルミホイルで遮光後, $4{ }^{\circ} \mathrm{C}$ の低温室に保存し, その安定性について検討した。但しNerについては室温 で保存し，その測定はTDI（サーマルデソープションイ ンジェクター, ジーエルサイエンス社製）による加熱脱 着後, GC/FIDにより行った。その結果を表 2 に示す。

Table 2 Recoveries after storring samples

\begin{tabular}{crc}
\hline \multirow{2}{*}{ Storage } & \multicolumn{2}{c}{ Recovery $(\%)$} \\
\cline { 2 - 3 } day $)$ & Nereistoxin & Thiophanate-methyl \\
\hline 1 & 99 & 99 \\
2 & 102 & 92 \\
3 & 110 & 80 \\
7 & 88 & 71 \\
\hline
\end{tabular}

Ner は比較的安定であるが, TM は分解しやすいので, できるだけ速やかに分析する必要がある。

\section{5 大気の分析例}

図 1 にNerの標準試料と大気試料の SIM (Selected ion monitoring）クロマトグラムを示す。常温吸着捕集と TCT 法による GC/MS 分析は, 繰り返し分析ができな いという久点はあるものの, 全量分析が可能であるので, GC 分析が可能な低濃度物質に対しては非常に有用な方 法と思われる。

図 2 にTMの標準試料と大気試料 (サンプル 3 個を合 わせて処理)の分析例を示す。今回 TM は検出されなかっ たが，HPLC/UV 法による測定では共存物質による影響 も考えられるので, 相当する保持時間にピークが現れた 場合, 以下の方法で確認することが必要である。

（1）測定波長を変える。（2）溶離条件を変える。 たとえばメタノール濃度を変える。（３）TMはアルカ リ性溶液では非常に不安定で分解するので9), 試料の一 部をアルカリ性のまま処理して分析することにより分解 の有無を確認する。( 4 ） TM は農作物に散布されると 加水分解し, MBC (カルベンダジム) となることから, TMが実際に存在するなら MBC も存在すると思われる ので, $\mathrm{MBC}$ の存在を蛍光分析でたしかめる5)。以上の 方法でさらなる確認は可能と思われるが, 多くの手間も

$(\Lambda)$

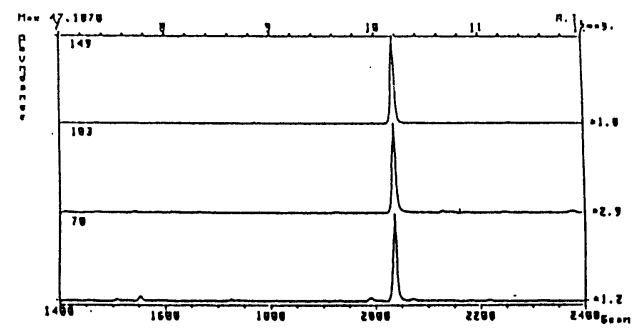

(B)

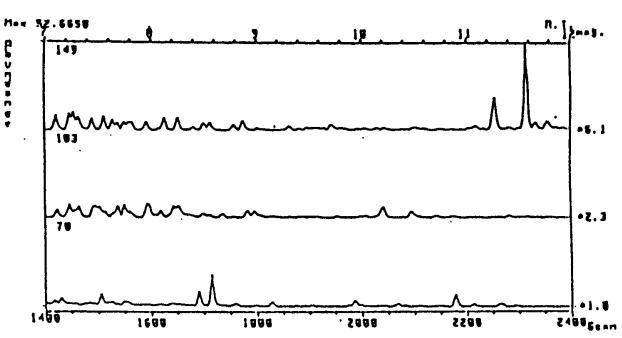

Fig. 1 GC / MS - SIM chromatograms of nereistoxin.

(A): Standard, (B) : ambient air. The chromatographic conditions; column temperature $80^{\circ} \mathrm{C}$, initial temperature, to $165^{\circ} \mathrm{C}$ at $5{ }^{\circ} \mathrm{C} / \mathrm{min}$ and then program med to $250^{\circ} \mathrm{C}$ at $10^{\circ} \mathrm{C} / \mathrm{min}$, followed by an isother mal hold at this temperature for $4.5 \mathrm{~min}$. 


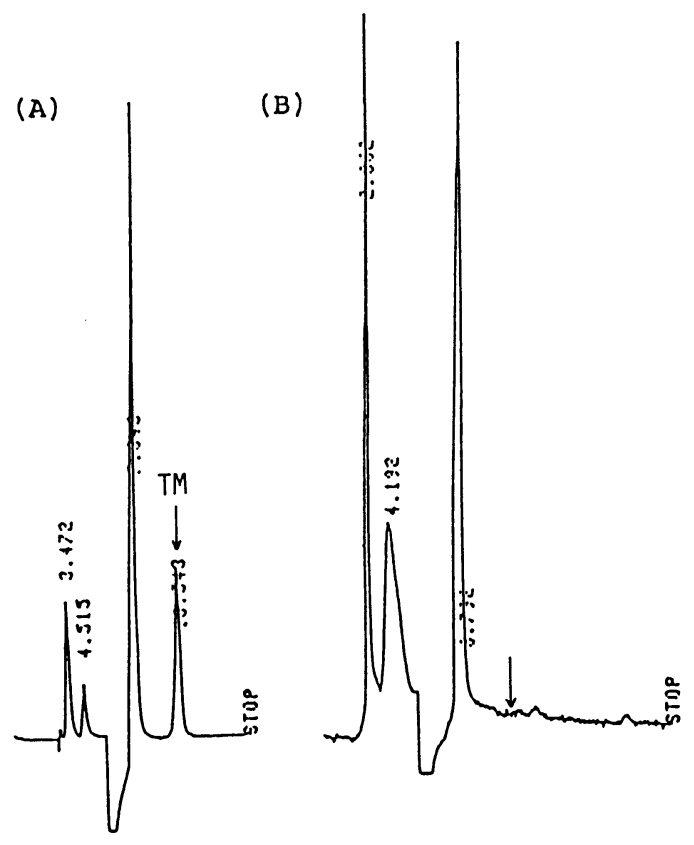

Fig. 2 High performance liquid chromatograms of thiophanate-methyl by using UV detector (wavelength, 270nm). (A): Standard, (B): ambient air.

かかり TM の検出下限も高いため, 硫黄選択性化学発光 検出器 (sulfur-selective chemiluminescence detector) $)^{101}$ のような高感度，高選択性の検出器の普及が望まれる。

本研究は環境庁保健調査室の平成 3 年度委託調査とし て行われ，1992年 2 月，第 9 回環境科学七ミナーにおい て発表したものに加筆したものである。

\section{要 約}

大気中のカルタップの分析法として，大気試料を Carbotrap ${ }^{\mathrm{TM}}$ に吸着捕集し，TCT 法により GC/MSに導 入し，ネライストキシンとして測定する方法を，又チオ ファネートメチルの分析法としてアスコルビン酸含浸ろ 紙による捕集と HPLC/UV 法による測定法を開発した。
ネライストキシンの検出限界は, 試料採取量 $30 \mathrm{~L} て ゙$ $0.3 \mathrm{ng} / \mathrm{m}^{3}$ であり，チオファネートメチルは $200 \mathrm{~L}$ 採取試 料を 5 個処理した場合で, $22 \mathrm{ng} / \mathrm{m}^{3}$ である。ネライスト キシン，チオファネートメチルの両物質とも大気中では 検出されなかった。

\section{文 献}

1）環境庁環境保健部保健調查室編：平成 2 年版化学物 質と環境，3，p.157，171，(1990）

2）奥村為男：大気中農薬の捕集剤としてのフロリジル およびシリカゲルの評価，大気污染学会誌，27, 45-57, (1992)

3）鈴木 茂：ガスクロマトグラフ質量分析計による農 薬の一斉分析，分析化学，41，115-124，(1992）

4) Osugi, T. and Masuda, K..: A convenient colorimetric determination of cartap hydrochloride and its insecticidal degradation product. J. Takeda Res. Lab., 35, 241-246, (1976)

5) Gilvydis, D.M. and Walters, S.M.,: Ion-Pairing liquid chromatographic determination of benzimidazole fungicides in foods. J. Assoc. Off. Anal. Chem., 73, 753-761, (1990)

6) 神浦俊一, 中土井 隆: 大気中のピリジン, 2 -ビ二 ルピリジンのキャピラリーガスクロマトグラ フィー・マススペクトロメトリーによる定量, 環境 化学, 1，567-570，(1991)

7) Nishi, K., Kodo, I. and Tan, N..: Nereistoxinのガスク ロマトグラフィー, J. Takeda Res. Lab., 29, 399-405, (1970)

8) Corcia, A.D. and Marcello, M.,: Multiresidue method for pesticides in drinking water using a graphatized carbon black cartridge extraction and liquid chromatographic analysis. Anal. Chem., 63, 580-585, (1991)

9) Ono, S. and Tohyama, N.:: 高速液体クロマトグラ フィーによるチオファネートメチルおよび関連化合 物の残留分析. J. Pest. Sci., 7，363-371，(1982)

10) Chang, H.C.K. and Taylor, L.T.,: Sulfur-selective chemiluminescence detection after packed-capillarycolumn high-performance liquid chromatography. Anal. Chem., 63, 486-490, (1991) 